\title{
Rediscovery and updated distribution of Lycodon septentrionalis from Mizoram state, north-east India
}

\author{
LAL BIAKZUALA ${ }^{1}$, VANLALHRIMA ${ }^{2}$, BINOY KUMAR BARMAN ${ }^{3}$ \& HMAR TLAWMTE LALREMSANGA ${ }^{1, *}$ \\ ${ }^{1}$ Developmental Biology and Herpetology Laboratory, Department of Zoology, Mizoram University, Aizawl, Mizoram, India-796004 \\ ${ }^{2}$ Biodiversity and Nature Conservation Network, Aizawl, Mizoram, India-796001 \\ ${ }^{3}$ Department of Geology, Mizoram University, Aizawl, Mizoram, India-796004 \\ *Corresponding author e-mail: htlrsa@yahoo.co.in
}

$\mathrm{T}$ he white-banded wolf snake Lycodon septentrionalis (Günther, 1875) is a nocturnal, terrestrial, colubrid snake known to feed on small vertebrates including snakes. It can reach up to $1,800 \mathrm{~mm}$ in total length and inhabits the midhills of evergreen forests at elevations ranging between 220 2,100 m a.s.I. (Das \& Das, 2017). The species is considered rare and there is little information on its natural history (Murthy et al., 1993). The known range of this species includes India (northern West Bengal, Assam, Arunachal Pradesh, Nagaland and Mizoram), Bhutan, Myanmar, Laos, Vietnam, Thailand, Cambodia, and China (Uetz et al., 2020). A total of only nine L. septentrionalis specimens have hitherto been reported from India (Das \& Vasudevan, 2015).

In this study, we document 10 new location records for $L$. septentrionalis in Mizoram state represented by four specimens we collected as well as information obtained from private collections and photographs (Fig. 1). The four collected specimens have been deposited in the Departmental Museum of Zoology, Mizoram University (MZMU). The locations for the ten new records are plotted in Figure 2 and the collection details are given in the Supplementary Material on the British Herpetological Society website (see note at the end of this article).

Lycodon septentrionalis can be diagnosed and distinguished from its sympatric congeners in the region by having a purplish-black dorsum with narrow transverse white bands and a white venter that is sometimes spotted or barred with black. This differs from other species - Lycodon zawi Slowinski, Pawar, Win, Thin, Gyi, Oo \& Tun, 2001 has poorly developed white cross-bands on a brownish black dorsum; Lycodon laoensis Günther, 1864 has yellow cross-bands on a brownish black dorsum; Lycodon fasciatus (Anderson, 1879) has yellowish cross-bars of irregular outlines on a black or purplish-black dorsum; Lycodon jara (Shaw, 1802) is striped all over with a yellow pattern being formed by small spots or short longitudinal lines on a brownish or purplish black dorsum; and Lycodon aulicus (Linnaeus, 1758) has white or yellowish cross-bars on a brownish or greyish dorsum. Moreover, we diagnosed the species by using an adult male specimen that had a maxillary bone extending beyond the palatine, bent inwards but not arched, with 7 anterior teeth increasing in size, fang-like, and a diastema separated the 7 anterior teeth from the other 5 teeth, the last three of them are larger than the others. In the case of other Lycodon species the maxillary bone is strongly arched and bent

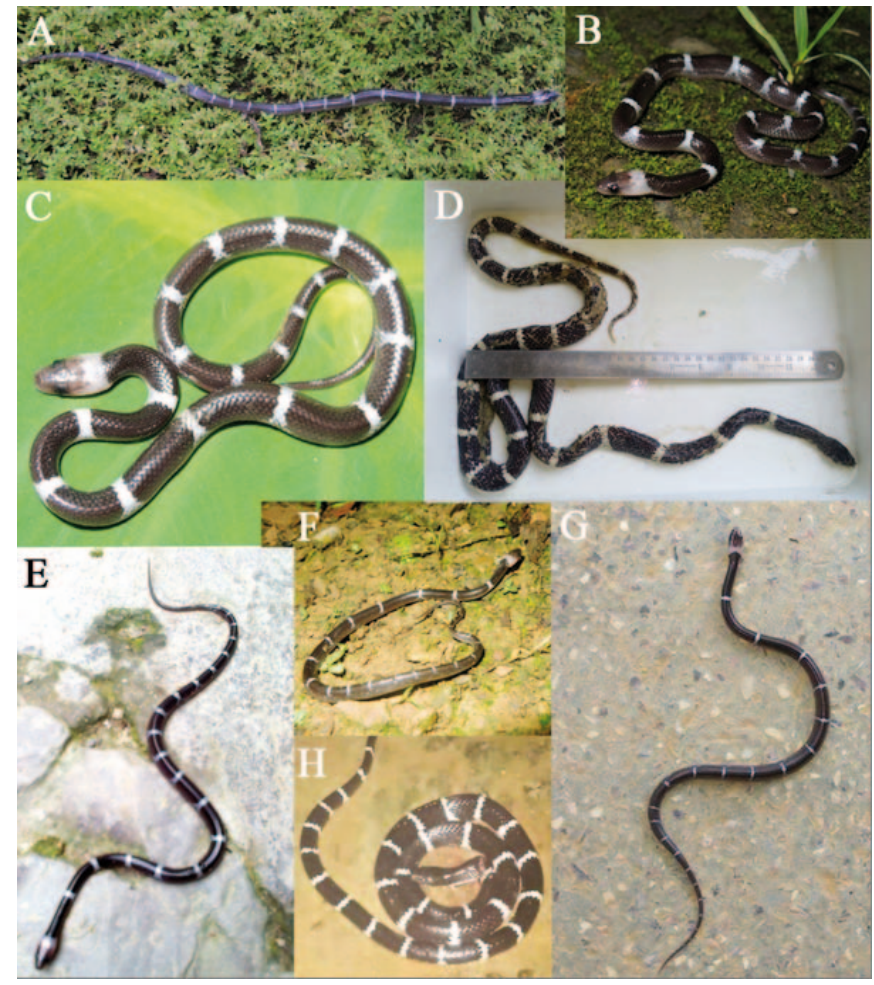

Figure 1. Lycodon septentrionalis from different localities in Mizoram, India; A. Juvenile collected from Sawleng; B. Juvenile found at Durlang; C. Juvenile from Chandmari West; D. Road-killed adult male from Mamit Jail Road, Mamit; E. Juvenile from Hunthar; F. Juvenile from Khawbung; G. Juvenile from PTS Thenzawl; H. Unsexed adult killed by local people at Khawrihnim

inwards anteriorly, with 3-6 anterior teeth increasing in size, fang-like, and separated by a toothless space from the rest 7-15 in number, the last two of which are larger than the others (Smith, 1943). Detailed morphometry and scalation data of four specimens were recorded (see Supplementary Material).

The first specimen of $L$. septentrionalis from Mizoram state was collected by T. G. Vazirani on 23 October 1960 (Z.S.I. Reg. No. 21904; snout-vent length=305 mm; tail length $=85 \mathrm{~mm}$ ) from Bhumtilong, ca. $16 \mathrm{~km}$ from Aizawl in the northern part of Mizoram (Talukdar \& Sanyal, 1978). Today, it is very difficult to be certain of this site as the name of the locality provided is nowhere to be found in the state. Moreover, Das \& Vasudevan (2015) plotted Bhumtilong in the location of Ratu village, in the north-eastern part of Mizoram 


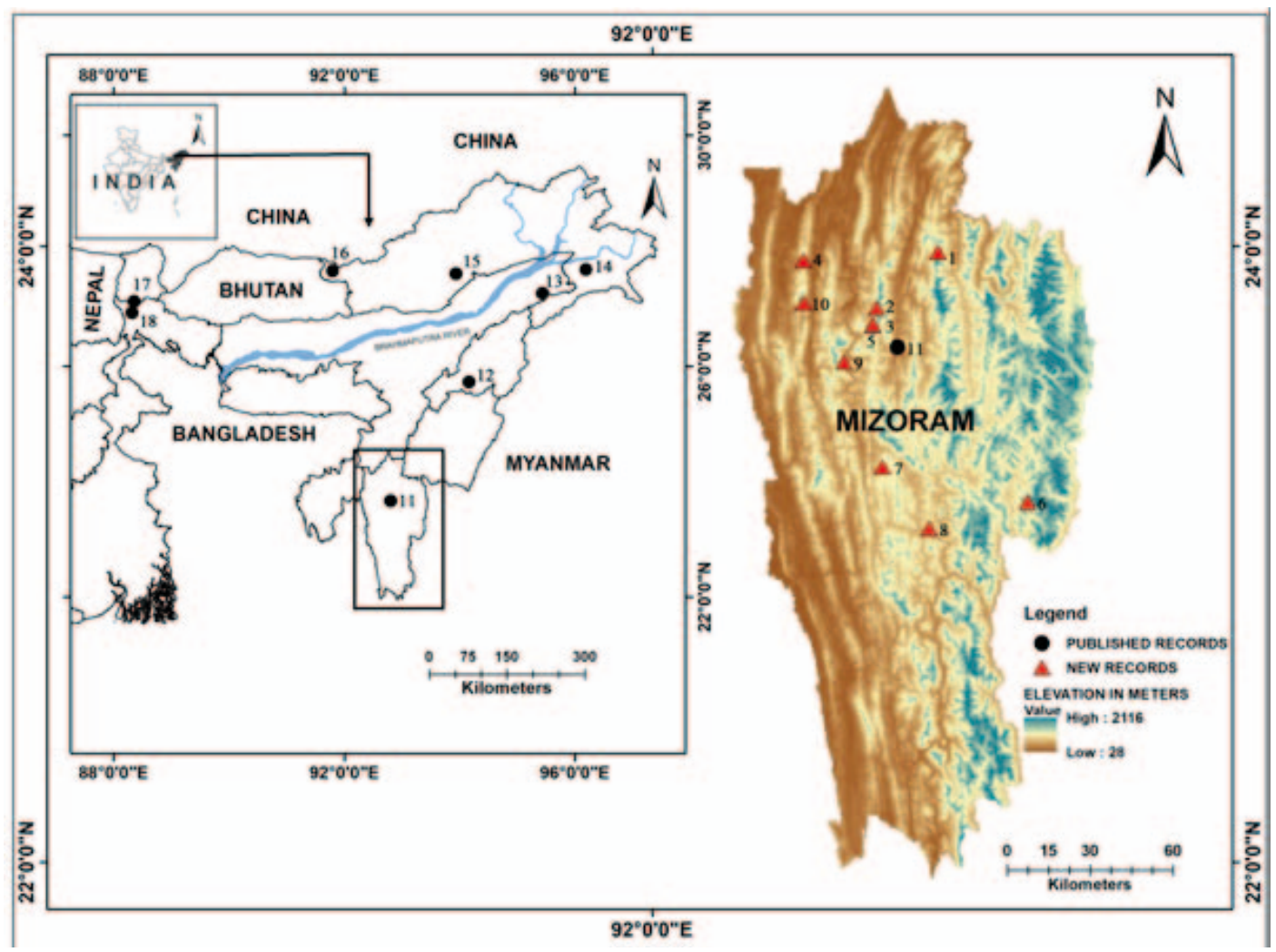

Figure 2. Map showing the distribution of L. septentrionalis in north-east India with emphasis on Mizoram state. The records 1 to 10 are new and from the following localities in Mizoram-1. Sawleng, 2. Durtlang, 3. Chandmari West, 4. Mamit Jail road, 5. Hunthar, 6. Khawbung, 7. Thenzawl, 8. Pangzawl, 9. Khawrihnim, 10. Dampu; 11 is the only previously published record from Mizoram(Bungtlang/Bhumtilong); 12 to 18 are published records from localities in other states (see Das \& Vasudevan, 2015) as follows- 12. Kohima, 13. Namsang, 14. Kahare, 15. Ziro, 16. Zimithang, 17. Darjeeling, 18. Phubsering

which is ca. $143 \mathrm{~km}$ from Aizawl. We suggest the locality is Bungbangla (Bungalow) formerly known as Bungtlang located at ca. $16 \mathrm{~km}$ from Aizawl ( $\left.23^{\circ} 43^{\prime} 47^{\prime \prime} \mathrm{N}, 92^{\circ} 46^{\prime} 46^{\prime \prime} \mathrm{E}\right)$ in the northern part of Mizoram state where the state government constructed an inspection bungalow and later a guest house (C. Vanlallawma, pers. comm.).

Lycodon septentrionalis has not been reported from Mizoram for 60 years after it was first collected. Our new records were made between 2013 and 2019 and constitute the southernmost localities in India at altitudes ranging from $703 \mathrm{~m}$ to $1310 \mathrm{~m}$ a.s.l. (Fig. 2) and represent a rediscovery of this species within the state, with confirmation of its occurrence in five Mizoram districts. It may be inferred that L. septentrionalis is not an uncommon species in Mizoram which is not surprising as until recently the ophidian fauna of Mizoram had remained very poorly surveyed.

\section{ACKNOWLEDGEMENTS}

We are thankful to the Chief Wildlife Warden, Department of Environment, Forests and Climate Change, Government of Mizoram for issuing permissions (No.A.33011/2/99CWLW/225) for herpetofaunal collection within the state. We also thank Department of Science and Technology-Science and Engineering Research Board (DST-SERB), New Delhi, India for providing financial assistance. Heartfelt thanks to Dr. Karthikeyan Vasudevan for providing reading materials and valuable comments on this work. We acknowledge
T.B.C. Lalbiaknunmawia, Vanlalhruaia, Doma Hnamte, Paul L. Hmar, Mapuia Hnamte, Sangtea Ralte Lelhchhun, Ruatfela Hlondo, Rodinmawia Chawngthu, Angaiha Chawngthu, Lalmuansanga, and Ht Decemson for their field assistance.

\section{REFERENCES}

Das, A. \& Vasudevan, K. (2015). Notes on the distribution and natural history of Dinodon septentrionalis (Günther, 1875) from India. Hamadryad 37: 127-131.

Das, I. \& Das, A. (2017). A Naturalist's Guide to the Reptiles of India, Bangladesh, Bhutan, Nepal, Pakistan and Sri Lanka. Prakash Books India Pvt. Ltd., New Delhi. 176 pp.

Günther, A. (1875). Report of Indian Reptiles obtained by the British Museum. Proceedings of the Zoological Society of London. $568 \mathrm{pp}$.

Murthy, T.S.N., Sanyal, D.P. \& Duttagupta, B. (1993). Rare snakes of India. The Snake 25: 135-140.

Smith, M. A. (1943). Fauna of British India, Ceylon, and Burma, Including the Whole of the Indo-Chinese Subregion. Reptilia and Amphibia, Vol. III. Serpentes. Taylor and Francis, London. xii + 583 pp.

Talukdar, S.K. \& Sanyal, D.P. (1978). Four new records of reptiles from Mizoram. Bulletin of the Zoological Survey of India 1: 319-320.

Uetz, P., Freed, P. \& Hošek, J. (2019). The Reptile Database. http://www.reptile-database.org. (accessed March 2020).

Accepted: 28 April 2020

Please note that the Supplementary Material for this article is available online via the Herpetological Bulletin website: https://thebhs.org/publications/the-herpetological-bulletin/issue-number-152-summer-2020 